\title{
Green PR Approach in Deforestation Control of Kamojang Nature Reserve Area
}

\author{
Indriyanti Kamil \\ Langlangbuana University \\ Bandung, Indonesia \\ rindriya73@gmail.com
}

\begin{abstract}
Along with the growing population and the development of various industries, environmental issues have become a serious problem faced by humans. The problem of environmental destruction has begun to be loudly voiced by people in different parts of the world. This happens because of the impact of forest destruction due to illegal logging, clearing land for agriculture, shelter and industrial estate. Deforestation in the Kamojang Nature Reserve area is caused by human intervention and requires serious attention from government, stakeholders and the community. To address environmental degradation the government should educate the community and work with locally active people, involved in the natural resource management processes it contains. In Indonesia, government programs aimed at educating the public about the importance of preserving the environment are very limited. Natural Resources Conservation Agency (BKSDA) West Java as one of the government agencies that have the main tasks and functions as forest conservation institutions, plants, education, research, and ecotourism implement the program of Green Public Relations consisting of two programs namely the implementation of protection of nature reserves, nature parks, village conservation model hunting park (MDK) and environmental education programs. This study analyzes the implementation of environmental programs BKSDA Region 5 Garut Regency by using the strategic approach of environmental PR involving Public Relations BKSDA West Java and forest conservation units as primary data source. This study identifies that public relations strategies are not only implemented to develop crisis programs but are also relevant for developing Green Public Relations programs such as the BKSDA West Java.
\end{abstract}

Keywords-green public relation; natural resource conservation; environmental communication

\section{INTRODUCTION}

The Natural Resources Conservation Center (BKSDA) of West Java is targeting to rehabilitate forests and land of approximately 2,000 hectares (ha) degraded to function and be restored to protected areas by 2018 [1]. In West Java there are 50 conservation areas with an area of nearly 83 thousand ha more than Pangandaran until Sangiang Island. Of this area, approximately 3,500 ha of land in five open access areas are degraded with various causes. Such as forest fires, encroachment, illegal grazing, rock and sand mining, and logging. Taman Wisata Alam Kawah Kamojang is one of the areas that suffered environmental damage. To suppress threats and land encroachment in nature conservation areas, BKSDA
West Java involves communities to defend protected areas and conservation with the concept of inclusiveness of conservation areas. To overcome the degradation of various things done. Including community involvement in managing and participating in maintaining conservation areas. This community involvement, using the concept of environmental services or ecotourism so that people can receive economic benefits while maintaining the conservation area.

The condition of environmental crisis in West Java thus demands awareness from various parties to take part in doing remedial action. Responses related to these environmental issues are more quickly followed up by private companies that are turning to the concept of "green initiative" to run their business.

Edelman as one of the world's leading public relations consultants in 2007 conducted a survey about going green initiatives on conformity behavior. The results of this survey show that $85 \%$ of consumers intend to change (replace) their brand to support companies that are active in CSR and environmental activities. The facts reveal that environmental issues have involved public relations practitioners to commit to the concept of green public relations implemented through CSR programs and community development run by the company. Unfortunately, government public relations or public relations from government agencies has not been much involved in responding to environmental issues.

Government public relations or public relations government is one institution that is in a realm of bureaucracy. In the Decree of the Minister of Communication and Information Technology Number 371 / KEP / M.KOMINFO / 8/2007 concerning the Code of Ethics of Public Relations of the Government Article 6, it is mentioned that the public relations public is all actions undertaken by an agency / entrepreneur in an effort to foster harmonious relationships with internal audiences and externally and fostering the dignity of institutions / governments in the view of internal and external audiences in order to gain understanding, trust, cooperation, and support from internal and external audiences in the implementation of basic tasks and functions [2].

From the above definition described that public relations government has a very strategic role. Public relations government is the spearhead in delivering government programs and performance. In addition, public relations as a 
mouthpiece or source of information, is required in the ability to face challenges and changes in the era very quickly, especially facing the development of technology, information and communication. Public relations government should be able to synergize / partner with journalists (Print Media, Electronic Media and Social Media), as well as other press agencies in helping the government to disseminate information on development programs to the public.

Public relations is a management function that assesses public attitudes, identifies the policies and ordinances of a person or organization for the public interest, and plans and conducts an activity program to gain understanding, understanding and support from public [3]. But in reality, not all public relations publications in Indonesia to maximize its function. There are still many public relations officers who are trapped in institutional imaging efforts, so its role as a communicator to pub like is still very limited, including public relations public awareness to communicate environmental issues to the public still untouched. With the limited role of government public relations in communicating the message of the environment to the community, the public awareness is also low in maintaining the environment.

Natural Resources Conservation Agency (BKSDA) West Java as one of the government agencies that have the main tasks and functions as forest conservation institutions, plants, education, research, ecotourism and implement the program of Green Public Relations consisting of two programs namely the implementation of the protection of nature reserves, nature parks, village conservation model hunting park (MDK) and environmental education programs. These efforts are oriented towards the concept of green public relations involving the role of public relations institutions. Research on green public relations is still limited, this study will analyze the implementation of green public relations concept conducted by public relations at Natural Resources Conservation Center to develop an effective strategy in responding to environmental issues and efforts made by public relation agencies in BKSDA in educating the public of the importance of preserving the environment.

\section{LITERATURE REVIEW}

\section{A. Public Relations Government}

Public Relations Government is a part of government agency that has duty and main function in bridging good relationship between government and society with various effort and action in disseminating information about government policy and development program, managing public opinion while also managing reputation of government with emphasis on public service.

The task of public relations can be detailed as follows [4]:

- Observe and learn about the desires, aspirations and aspirations of society (Learning about desires and aspiration).

- Activities that provide advice or suggestions to respond to what the government should do as the public desires (advising the public about what is should desire).
- Ability to cultivate good relationship between society and government (ensuring satisfactory contact between public and government officials).

- Provide information and information about what an agency or government agency is seeking (informing and about what an agency is doing).

Public Relations in running its role to do various strategies through several aspects of the approach are as follows:

- Persuasive and educative approach

The function of public relations is to create two-way communication (reciprocity) by disseminating information from the organization to the public who are educating and illuminating or with a persuasive approach, in order to create mutual understanding, respect, understanding, tolerance and so forth.

\section{- Cooperative approach}

To expand the role of public relations in the community then public relations in a narrow sense only represents the institution / institution. But its broader role is to participate in supporting the national development program, realizing national resilience in the field of politics, economy, social culture and security.

\section{B. Perspective of Green Public Relations}

Environmental issues have demanded that many companies apply the concept of eco brand, which also extends to the world of public relations that gave birth to the concept of green public relations. green public relations are a sub-division of public relations that communicates eco-friendly practices through corporate CSR programs or other public communication campaigns. The goal is to increase brand awareness and enhance the company's reputation. Some of the programs carried out include publishing news articles, giving awards to environmental conservation figures, collaborating with environmental groups and distributing publications [5].

The concept of green public relations is closely related to environmental issues that can have an impact on corporations or companies. Environmental public relations issues that have occurred or have not happened to the company will cost a lot. In the current situation, managing environmental profiles and relationships have become part of corporate communication actions.

Once one issue is identified and the SWOT analysis has been met, the PR should make a plan to identify the public and establish the priority scale in the face of the crisis. Companies must be careful to prepare communication plans and programs that will be run to cope with the crisis. Crisis planning is an integral part of the Environmental Public Relations (EPR). The common approach used in EPR is A Strategic Approach to Environmental Public Relations which includes the following stages [6]:

- Mapping and Problem Analysis

- Planning

- Collaboration partners 
- Monitoring and Evaluation.

\section{RESEARCH METHOD}

This study is discussed using qualitative descriptive method. Primary data obtained through observation in the Natural Resource Conservation Center Kamojang Garut as an object of study will be analyzed using A Strategic Approach to Environmental Public Relations approach. Data collection involves informants from public relations and technical implementers at BKSDA.

\section{RESUlt AND DiscuSSION}

Natural Resource Conservation Center, or BKSDA, is a technical unit of echelon III level (or echelon II for a large hall) under the Directorate General of Forest Protection and Nature Conservation of the Ministry of Environment and Forestry of the Republic of Indonesia [1]. This agency is responsible for managing conservation areas, especially forests of nature reserves (wildlife reserves, nature reserves) and natural tourism parks

In addition, Balai KSDA is also responsible for supervising and monitoring the circulation of protected plants and animals in its territory; including monitoring the efforts of breeding and maintaining of plants and animals protected by individuals, corporations and conservation agencies concerned. As a government agency in charge of implementing conservation efforts, BKSDA Section III Garut region is responsible for implementing protection and security, preservation of biodiversity (plants and wildlife) along with its ecosystem and sustainable utilization of biological natural resources and its ecosystem in its working area. Kamojang is under coordination BKSDA Section III Garut district. Therefore, to implement conservation efforts in the Conservation Area Kamojang required the participation of all human resources owned conservation Center of natural resources both the conservation and the role of public relations institutions in environmental communication. The discussion on this analysis will limit the role of public relations institutions at Natural Resources Conservation Center Section III as the compilers of green public relations programs that are oriented towards educating the community related to environmental communication.

\section{A. Mapping and Problem Analysis}

Public relations institutions play a role in environmental communication activities. To maximize the implementation of these activities, BKSDA Garut region has compiled and analyzed its potentials using SWOT analysis by considering the strength, weakness, opportunity, and threat factors related to basic tasks and functions of Natural Resources Conservation Center as follows:
TABLE I. SWOT ANALYSIS

\begin{tabular}{|c|c|c|c|}
\hline Strength & Weakness & Opportunity & Threat \\
\hline $\begin{array}{l}\text { BKSDA as } \\
\text { Conservation } \\
\text { and Nature } \\
\text { Conservation } \\
\text { Agency that } \\
\text { protect } \\
\text { Kamojang area }\end{array}$ & $\begin{array}{l}\text { Human } \\
\text { Resources and } \\
\text { limited } \\
\text { environmental } \\
\text { counselors }\end{array}$ & $\begin{array}{l}\text { The existence } \\
\text { of the } \\
\text { community, } \\
\text { volunteers and } \\
\text { concerned } \\
\text { NGOs }\end{array}$ & $\begin{array}{l}\text { Increased } \\
\text { environmental } \\
\text { damage caused } \\
\text { by } \quad \text { illegal } \\
\text { mining, forest } \\
\text { fires, land } \\
\text { conversion, and } \\
\text { hunting wildlife }\end{array}$ \\
\hline
\end{tabular}

From the data can be formulated 4 alternative strategies of environmental communication by combining internal and external factors that can be implemented in Natural Resources Conservation Center are: 1). Strength Strategy - Opportunity: Need to create environmental conservation cooperation program by empowering society. 2). Weakness Strategy Opportunity: Effectiveness of Human Resources performance capable of communicating the importance of conservation area conservation and nature reserves to the community. 3). Strategy Strength - Threats: Needs to create programs that can provide understanding to the community about the importance of maintaining natural resources. 4). Weakness Strategies Threats: Human resource and extension personnel competencies are required to create a universal message of environmental communication.

\section{B. Planning}

Program planning still refers to the main tasks and functions of the BKSDA as a hall for conservation, education, and ecotourism. At the stage of preparation of the program involves all elements of policy makers in the BKSDA ranging from Head of UPT Conservation and Nature Reserve, Section Kamojang area, team of Planners, and Public Relation because the program will be planned to have inter-unit linkages. Program Determination There are two planned program formulas:

- Cooperation of environmental conservation with community empowerment program.

- Public education on the importance of conservation areas and reserves nature.

Media Utilization and Communication Strategy. In practice the public relations communication BKSDA uses different media and communication techniques because the targeted public segments are different.

Two formulations of the program are then elaborated into BKSDA work program include:

- Natural Resources and Ecosystem Conservation Programs by way of recovery and reclamation of degraded conservation areas

- Environmental education program as education for the community about the importance of maintaining the area and the preservation of nature. 


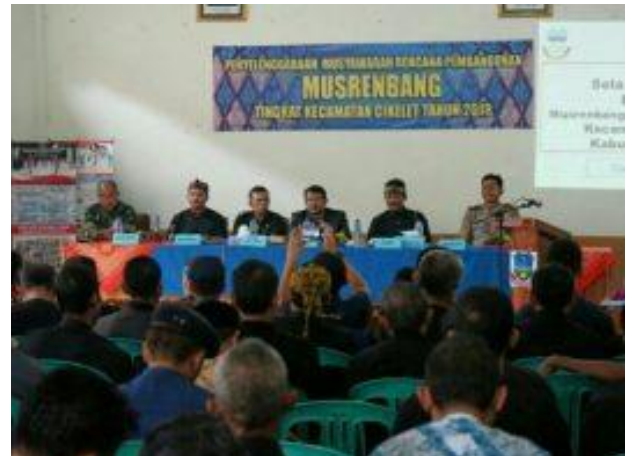

Fig. 1. Counseling and Practice of Environmental Communication in Cikelet Garut Village

The communication strategy is carried out by BKSDA public relations by enhancing cooperation among stakeholders, Strategy to increase and expand partnership between government, private sector, non-governmental organizations and community to take an active role in protecting conservation area from environmental damage. This communication approach requires public relations with good negotiation skills. Environmental education program, conducted with Focus Group Discussion (FGD) activities using brochures, audiovisual media, exhibitions, modules, and interactive games to arouse the public interest.

\section{Collaboration Partners}

In the public relations communication activities BKSDA coordinate and collaborate with the sharing of parties among others; local government district garut, non-governmental organizations, environmental activists and nature lovers, stakeholders, community leaders, pesantren kamojang region and the world of education. Humas Natural Resources Conservation Center conducts interactive and intensive communication with the parties in collaborative management effort of kamojang conservation area. Kamojang conservation area is an area that has high typology of pressure so that the need of collaboration of the parties in efforts to protect and rehabilitate the region.

\section{Monitoring and Evaluation}

Monitoring and evaluation activities are conducted by Natural Resources Conservation Center in the implementation of the program. In its implementation Garut Conservation Center has run the monitoring and evaluation process of two green public relations programs running. The evaluation was conducted by the Functional Assessment Technical Evaluation Team (EKF) consisting of BKSDA, Lipi, academics, stakeholders.

\section{CONCLUSION}

Environmental communication activities in the conservation area and nature reserve Kamojang conducted by public relations BKSDA Garut region with reference to the program and vision Conservation Center of West Java. A Strategic Approach to the Environmental Public Relations used to guide PR in preparing programs anticipate the occurrence of a crisis that can befall a company, given the issue of environmental damage has become a global problem that requires care from various parties. The strategic approach of Environmental Public Relations can be adopted and implemented in preparing the green public relations program. Green public relations program at Garut Conservation Center of Garut is prepared using the approach of Environmental Public Relations (EPR) which steps are simple and put HR Pranata Humas as subject of program implementer.

\section{REFERENCES}

[1] Balai Konservasi SDA Garut. Visi http://www.bksda.jabar.com/id/visi.php (Retrieved September 20, 2017).

[2] Menteri Komunikasi dan Informatika. Keputusan Menteri Komunikasi dan Informatika Nomor: 371/KEP/M.KOMINFO/8/2007 tentang Kode Etik Humas Pemerintahan. Jakarta, 2007. PRWorld. Let's Talk Green PR Sebuah Perspective. 2014.

[3] M. Cutlip Scott, Allen H. Center and Glen M. Broom, Effective Public Relation. Jakarta: Kencana Prenada Media Group, 2009.

[4] J.D. Millett, Management in The Public Service: the Quest for Effective Performance. New York: McGraw Hill Book Company, Inc. 1954.

[5] J. Sarvaes, Sustainable development and green communications. New York: Palgrave Macmil- lan, 2013.

[6] C.L. Caywood, The Handbook of Strategic Public Relations \& Integrated Communications. USA: McGraw-Hill, 1997. 